\title{
Boustene vir die toekoms van die NG Kerk (Deel III) ${ }^{1}$
}

\author{
ABSTRACT \\ Directives of the future for the DR Church (Part III)
}

The DR(NG) Church, besides its own thinking and theologising, is influenced by the sphere of the new political and cultural situation as well as the sphere of the postmodern paradigm. These factors bring challenges for the way in which the DR(NG) Church understands itself as a church and its mission within the South African context. In meeting these challenges the church has to have a historical understanding of these influences within its context. From this historical understanding norms and values could be deducted to serve as contextually relevant directives for the future. Consequently they will also contribute to shaping the future of the DR(NG) Church.

1.

INLEIDING

"Die sinikus sal bly sê dat wat die mens uit sy geskiedenis leer, is dat die mens nie uit sy geskiedenis leer nie. Natuurlik bestaan die geskiedenis nie uit 'n reeks ... eenvoudige "lessies" nie, maar deur die verlede ... te bestudeer, verkry 'n mens wel kennis en insig wat aangewend kan word om vraagstukke in die hede op te los en die toekoms te beplan." (Wessels, 2001:257). Moltmann (1989:321, 323) meen ook dat 'n bewustheid van die geskiedenis die moontlikheid skep om oor die toekoms na te dink. As mense die effek van die geskiedenis beleef, begin hulle oor die betekenis daarvan en hulle lewensdoel nadink - óf ten goede óf ten slegte. Historiese bewustheid het vir Moltmann $(1989: 327,330,332)$ te make met 'n kritiese beskouing van die geskiedenis, sodat ' $n$ persoon begrip kan hê vir die omvang van die invloed van dít wat voortvloei uit die verlede na die hede. Die wyse waarop daar omtrent die omvang van die invloed beslis word, hang saam met mense se hoop of vrees vir die toekoms. Die inhoud van hierdie hoop of vrees hang op hulle beurt saam met die dinge waarop mense se bestaan gerig is en waarop hulle vertrou.

Die effek van die tyd waarin die NG Kerk hom tans bevind, het in so 'n mate 'n invloed op die kerk dat dit uitgedaag word om oor die betekenis daarvan vir sy kerkwees en identiteit na te dink. Taber (2002:184) maak'n opmerking oor die kerk in Suid-Afrika: "[T]he church cannot view itself as an agent of change in South Africa. It is itself an object of change." Daarom wys Durand (2002:16) daarop dat die kerk inderdaad gedwing word om hom af te vra hoe hy verander, sonder dat hy deur sy politieke, ekonomiese en sosiale omgewing voorgeskryf word. Die kerk behoort dus te bepaal in watter mate die omvang van dié invloed vir die lewe en identiteit van die kerk behoort te geld, al dan nie. Burger (2001:15) sê dat die implikasies hiervan vir die kerk op minstens drie vlakke lê: die bediening van die kerk, die taak of missie van die kerk en die

1 Artikel gebaseer op 'n hoofstuk uit 'n MA-verhandeling (Teologie) by UP (2008) getitel " $n$ Dowwe spieël: 'n kerkhistoriese ondersoek na die resente stand van die NG Kerk, 1990-2006" en ingedien deur ds P Kruger van die NG Gemeente Nigel-Suid onder die studieleiding van prof JW Hofmeyr. 
identiteit van die kerk. Hofmeyr (2002a:243) se opmerking bevestig dit as hy meen dat die era sedert 1994 die NG Kerk uitdaag om 'n sterker en duideliker historiese bewussyn te ontwikkel en dat die kerk se identiteit, gereformeerdheid en spiritualiteit hergedefinieer moet word.

In 'n poging om sy identiteit, taak en bediening te herdefinieer, is dit belangrik om te let op die konteks waarbinne die NG Kerk bestaan, want dit sal bydra tot die keuses wat die kerk gaan maak. Sodoende kan daar aan norme en waardes wat persoonlik en sosiaal rigtinggewend is, gebou word. Indirek sal dit ook bydra tot die vorming van 'n nuwe identiteit vir die kerk. Aan die hand van die volgende word gepoog om aan te dui hoe die nuwe identiteit van die kerk (NG Kerk) daar behoort uit te sien.

\section{UITDAGINGS AS GEVOLG VAN DIE POLITIES-KULTURELE SITUASIE SEDERT 1990 WAT 'N ROL BEHOORT TE SPEEL IN DIE UITBOU VAN DIE NG KERK SE IDENTITEIT.}

In die kritiese beskouing van die konteks van Suid-Afrika se polities-kulturele situasie sedert 1990 en die invloed daarvan op die NG Kerk, kom 'n historiese bewustheid na vore wat met die volgende verband hou:

Eerstens: Uit die NG Kerk se historiese erfenis van apartheidsteologie word dit duidelik dat daar 'n waaksaamheid teen teologie se vereenselwiging met politieke modelle moet wees, dat daar teen 'n sekulêre teologie ('n teologie wat deur sy konteks voorgeskryf word) gewaak moet word en dat godsdiens nie met die rassekwessie vermeng moet raak nie.

Tweedens: Die proses van politieke transformasie daag die NG Kerk uit om begrip vir lidmate se reaksie op radikale transformasie te toon, sowel as die weerstand teen verandering as gevolg van die groeiende diskontinuïteit met die gebruike en oortuigings van die verlede.

Derdens: Suid-Afrika se nuwe kulturele situasie vra 'n beslissing van die NG Kerk oor hoe hy hom identifiseer met die nuwe geldende politieke, sosiale en ekonomiese strukture. Dié situasie vereis van die NG Kerk kruis-kulturele dialoog met ander kerke en 'n beweging na ekumenisiteit.

Begrip vir hierdie bogenoemde sake wat voortvloei uit die verlede na die hede, bepaal hoe oor die invloed daarvan op die NG Kerk beslis behoort te word. Norme en waardes kan hieruit verkry word wat persoonlik en sosiaal rigtinggewend is deurdat dit boustene kan word vir die identiteit van die NG Kerk in sy huidige kulturele konteks. Hierdie boustene word vervolgens bespreek.

\section{Bousteen 1: Verstaan die polities-kulturele psige van die Afrikaner.}

Die NG Kerk het geleer wat dit inhou om 'n spesifieke politieke model teologies te ondersteun. Dis onwaarskynlik dat die kerk weer in so 'n situasie sal beland. Dit bring ook mee dat daar teen 'n sekulêre teologie (soos die apartheidsteologie) gewaak moet word. Ongelukkig beteken dit nie dat die teologiese idees en ou politieke waardes van apartheid in mense se psiges afgeskaf is nie. Hoewel moderne Afrikaners dalk nie meer die vroeëre idees nougeset handhaaf nie, het die destydse kollektiviserende kyk na die mensdom oorgebly. In 'n artikel in die Kerkbode van 21 Maart 2008, wat daaroor handel dat die NG Kerk en sy leierskap die uitdaging wil aandurf om rassisme te beveg, word dr Kobus Gerber, algemene sekretaris van die NG Kerk, aangehaal: "Ons was baie naïef om te dink dat dit sommer vanself weggaan. Dit is ' $\mathrm{n}$ reus wat doelgerig onder alle rasse beveg moet word." (Oosthuizen 2008:1). In die artikel word ook daarna verwys dat rassisme voorkom, omdat Suid-Afrikaners nog nie die veranderinge in die land vollediglik verwerk het nie. Die taak van die NG Kerk is om sy lidmate te begelei om hulleself daarvan te weerhou om andere kollektief binne kategorieë te beskou en daarvolgens veralgemenings te maak. Die nuwe kulturele situasie vereis 'n nuwe manier van dink en interaksie, waardeur die NG Kerk (en sy lidmate) se geloofwaardigheid by die res van die samelewing gewaarborg kan word. 


\section{Bousteen 2: Toon kritiese solidariteit met die belewenisse van lidmate in die nuwe Suid- Afrika.}

As gevolg van die NG Kerk se begrip van die erfenis van die apartheidsteologie was die NG Kerk huiwerig om na 1994 opsigtelik solidariteit met die lot van die Afrikaner te toon. Maar die Afrikanervolk waarmee die NG Kerk vir baie jare geïdentifiseer het, soek steeds solidariteit met die kerk en dit is tog verblydend dat die NG Kerk hierdie verantwoordelikheid besef (Gaum 1997:75). Lidmate wil hê dat die kerk met hulle vereenselwig, want hulle is immers die persone wat die kerk in stand hou, met die kerk meeleef en daarom ook solidariteit en geestelike leiding van die kerk verwag. Hierdie behoefte word verskerp as gevolg van lidmate se daaglikse blootstelling aan die markplein met sy ingrypende verandering. Daar is by lidmate dikwels 'n gevoel van bedreiging, diskontinuïteit en anemie. Jonker (1998:220-221) beskryf hierdie belewenisse: "Die droom van ' $n$ reënboognasie wat in vrede en veiligheid lewe, is ... nog nie bewaarheid nie. Talle bekwame jongmense emigreer, omdat hulle geen vertroue meer in die toekoms van die land het nie. Hoe moet wit Christene oor hierdie dinge oordeel? Moet hulle toegee aan negatiewe gevoelens ... ? Dit wil soms voorkom asof daar 'n kollektiewe swartgalligheid by ... lidmate van die kerk aanwesig is. Dit word ongelukkig versterk deur die bewuswording van die ... armoede en ellende van groot groepe van die landsbevolking, asook van korrupsie en verval op verskillende terreine en van kollektiewe onmag om daaraan te ontkom ... " Hanekom (2007:9) skryf ook hieroor: "Twyfel bestaan of lidmate al genoegsaam geleentheid gehad het om te rou oor 'n era en paradigma wat verby is. Verder blyk dit dat lidmate die woord 'kerkhereniging' maklik verwar met sensitiewe en soms pynlike sake soos grondhervorming, regstellende aksie en misdaad. Ons mense is seer, voel ontnugter en rou. Hulle sal emosioneel en teologies begelei moet word." Vir Durand (2002:19) is hierdie onherroeplike politieke situasie van die Afrikaner die rede hoekom baie lidmate die kerk se solidariteit verlang en die kerk beleef as die laaste oorblywende vesting van die Afrikanerdom. Die solidariteit wat getoon behoort te word, is 'n kritiese solidariteit waarin die kerk nie koud staan teenoor sy lidmate se wel en weë nie, maar ook krities staan teenoor hulle sonde (ook kollektiewe sondes) sodat daar 'n gesonde afstand gehandhaaf kan word (Gaum, 1981:36).

\section{Bousteen 3: Die kerk is 'n oop gemeenskap waarin ekumenisiteit ' $n$ wesenskenmerk is.}

Die NG Kerk het reeds die insig dat dit as wit, Westerse hoofstroomkerk nie meer alleen die Christelike norm in Suid-Afrika bepaal nie. Tesame met die voorkoms van groeiende pluraliteit en fragmentasie in die Nuwe Suid-Afrika, is ' $n$ beweging weg van denominasionaliteit na ekumenisiteit onvermydelik. Hierdie beweging is noodsaaklik, omdat die kerk ' $n$ belangrike versoeningsrol behoort te speel om mense met dieselfde waardes bymekaar uit te bring (Boshoff 1995:5). Vir Aleaz (2002:168) behoort kerke daarna te strewe om 'n 'community of communities' te wees. Daar kan 'n veelvoud van identiteite op 'n nie-bedreigende wyse aanvaar word. In so 'n gemeenskap is sosio-politieke-godsdienstige-kulturele werklikhede die hermeneutiese beginsel, omdat daar gepoog word om prosesse en ander tradisies te verstaan. Dit is noodsaaklik vir ekumenisiteit. In 'n proses soos die voortgaande herenigingsproses van die NG Kerk-familie (hoewel tans problematies) is dit noodsaaklik om voortdurend die hermeneutiese konteks daarvan te verreken - 'n konteks waarin prosesse, verskillende tradisies en die inhoud van mense se ervaringe verstaan moet word. Lidmate van die kerke in die familie sal toenemend aangemoedig moet word om, soos met die eerste waarde, op 'n nie-partikularistiese wyse te dink.

Die eerste drie waardes (boustene) kom voort uit die resente polities-kulturele situasie van Suid-Afrika. Vervolgens word aandag gegee aan waardes (boustene) wat deur die verandering in wêreldbeskouings na vore gebring word. 

ERA VAN VERANDERING WAT 'N ROL BEHOORT TE SPEEL IN DIE UITBOU VAN DIE NG KERK SE IDENTITEIT.

Smit (2001:121) meen die mees fundamentele verandering wat in Suid-Afrika plaasgevind het, is die feit dat dit oornag deel geword het van die tipiese [post]modernistiese, demokratiese, sekulêre, vryemark, pluralistiese gemeenskappe wat elders oor eeue ontwikkel het. Aangesien die kerk nie uitgesluit is van die invloed van die postmoderne denkraamwerk nie, kan die uitwerking daarvan in die algemeen waargeneem word in die religie en die lewe van die kerk (ook die NG Kerk). In die nadenke omtrent die invloed hiervan op die NG Kerk, kom ook 'n historiese bewustheid na vore wat met die volgende verband hou:

Ten eerste is daar sekere sake wat die NG Kerk, soos ook die kerk in die algemeen, raak. Die kerk beleef dat sy prominente posisie in die groter samelewing dramaties verander het en dat daar as gevolg van sekularisasie 'n groeiende onverskilligheid teenoor die kerk ontwikkel. Die kerk is ook nie meer die beskermer van absolute etiese waardes nie. In die algemeen beleef die kerk'n onsekerheid oor die weg wat dit moet volg wat deurdring tot die dieptes van die NG Kerk se gereformeerde belydenis en spiritualiteit. Dit maak die kerk kwesbaar vir die invloed van nuwe vorme van spiritualiteit wat 'n subjektiewe individualistiese inslag het. Gevolglik word die geloof geprivatiseer en kom die kerk onder die invloed van die verbruikersera se verbruikersmentaliteit. So word gemeentes binne hulle eie kontekste gedwing om in sekere opsigte die beginsels van die marksamelewing toe te pas om voort te bestaan en dit lei tot toenemende kongregasionalistiese tendense in die NG Kerk (Kruger 2008:159-168).

Tweedens bied die era van veranderende denksisteme ook uitdagings aan die teologie (op verskillende vlakke). Die tendens van relativering het implikasies vir die konsep 'waarheid' en Skrifinterpretasie. Daar is ook invloede wat betekenisvolle skuiwe in die teologie te weeg bring: die skuif weg van logiese positivisme na kritiese rasionalisme; die beweging weg van die groter gemeenskap na privatisme; die oorgang van denominasionaliteit na ekumenisiteit; die oorgang van die Eurosentriese era na die era van die mensheid (mensdom) as 'n geheel. Daar ontwikkel ook die noodsaaklikheid om voortdurend die invloed van die historiese en teenswoordige bewussyn te verreken (Kruger 2008:101-113). Daarom daag die era van verandering die teologie uit omtrent die beklemtoning van die uniekheid en universaliteit van Jesus Christus; die noodsaaklikheid om die sosiale betekenis van die Christelike verhaal te herbeskryf; die uitbou van die rol van die publieke getuienis van Christene en die kerk; die beoefening van ' $n$ meer kontekstuele en buigbare teologie (Kruger 2008: 172-176).

Weereens is dit belangrik dat begrip vir hierdie bogenoemde sake sal bepaal hoe oor die invloed daarvan op die NG Kerk beslis sal word. Nog norme en waardes kan hieruit verkry word wat persoonlik en sosiaal rigtinggewend is deurdat dit boustene kan wees vir die identiteit van die NG Kerk in sy huidige konteks.

\section{Bousteen 4: Desekulariserende missionêre verhoudinge moet gebou word.}

Die bevoorregte posisie van die NG Kerk in die samelewing het dramaties verander as gevolg van die invloed van sekularisasie. Daar sit 'n nuwe geslag Afrikaners op die banke van die kerk wat, soos Durand (2002:60-61) aandui, in die algemeen weinig moeite het om by 'n meer sekulêre openbare lewe aan te pas. Die strewe om enige vorm van Christelikheid in die openbare lewe uit te leef, ontbreek in die algemeen by hulle. Daar is van hulle kant af min kritiek teenoor die sekulêre verskynsels in die samelewing. Vir Van der Walt (1999:7-8) is hierdie tendens ' $n$ groot gevaar vir die Christendom vandag, aangesien sekularisasie aan godsdiens min betekenis gee in die publieke, openbare terrein. Dit word beperk tot die persoonlike geloofslewe en die kerk. 
Hierdie tendens word baie maklik deur Christene aanvaar, omdat dit nie openlik die Christendom vervolg nie.

Durand (2002:64) meen egter dat die sekularisasieproses nie as iets negatiefs beskou moet word nie, omdat dit bydra tot 'n dekonstruerende proses waarin die Afrikanerwêreldvisie ont-ideologiseer word. Sodoende kan afstand verkry word tussen die Afrikaanse kerke en die samelewing waarin hulle staan en kan die NG Kerk opnuut fokus op sy roeping tot diens.

Die wyse waarop die kerk die sekulariserende tydsgees kan trotseer en sy posisie in die samelewing kan herstel, is deur missionêre verhoudinge tot stand te bring. In 'n artikel deur Erasmus (2004:7) waarin prof J Hendriks se strategiese prioriteite van die kerk in die toekoms bespreek word, word daarop gewys dat die kerk se missionêre wese herontdek moet word. Hunsberger (2002:103-104) wys daarop dat die kerk 'n gestuurde gemeenskap is vir die gemeenskap om hom. Die blote teenwoordigheid van die kerk behoort reeds iets van sy missionêre karakter te weerspieël. Die kerk kan dus nie 'n steriele afstand van die samelewing handhaaf nie, want die kerk behoort in die verkondiging van die Christelike geloof die relevansie daarvan vir die werklikhede van die alledaagse lewe aan te dui (Van der Walt 1999:47). Dit kan die kerk alleen regkry as dit kennis het van die ingewikkelde probleme van die moderne samelewing. Boshoff (1995:8) het 'n dekade tevore reeds aangedui dat die geloofwaardigheid van die Afrikaanse kerke toenemend gaan afhang van hulle betrokkenheid by die mens en sy alledaagse materiële en geestelike nood en sy soeke na sin en betekenis individueel en binne groepsverband.

Vir Durand (2002:71-72) kan die ontdekking dat die gemeente binne-in sy sendingveld leef, vir die Afrikaanse kerke een van hulle fundamenteelste vorms van transformasie beteken. Daarom moet die kulturele omgewing waarin die lidmate hulle bevind, ondersoek word en teologies oor nagedink word. Louis Becker, 'n lidmaat van die NG Gemeente Stellenbosch-Welgelegen, skryf in die Kerkbode van 13 Oktober 2006 dat verandering in die NG Kerk bewerkstellig kan word as Christene hulle rol in Suid-Afrika speel. Gemeentes wat reeds uitwaarts begin beweeg het, moet ook mekaar opsoek en hande vat om veranderinge in die kerk teweeg te bring. Dan sal die kerk 'n kragtige ontwikkelingsinstrument in Suidelike Afrika wees (Becker 2006:12). Dit is verblydend om te sien dat hierdie bousteen, om ' $n$ gestuurde kerk te wees, reeds as ' $n$ waarde geïdentifiseer is deur die Sinode Hoëveld (Handelinge van die Sinode Suid-Transvaal, 2005:234).

\section{Bousteen 5: 'n Nuwe normatiewe Christendom moet gebou word.}

Die NG Kerk en die kerk in die algemeen het met 'n oop samelewing te doen waarin die vryheid van die individu 'n groot rol speel (Boshoff 1995:19). Davie (1999:74) dui aan dat individualisme die kommunale basis van religieuse oortuigings en gedrag bedreig, omdat die normatiwiteit van godsdienstige oortuigings algaande in die private sfeer gebring word. Daarom het Christelike norme nou slegs betekenis in die persoonlike sfeer of hoogstens in 'n spesifieke groepsverband (Jonker, 1998:220). Omdat die oortuigings van die individu die maatstaf word vir wat normatief is, ontstaan daar wat waardes en norme betref, ' $n$ subjektivistiese ingesteldheid wat lei tot relativisme, utilisme, pragmatisme en egoïsme (Van der Walt, 1999:9). Dit skep 'n tweërlei probleme vir die etiek. Enersyds word die kerk se outoritêre manier om morele en ander gedrag voor te skryf, uitgedaag. Andersyds veroorsaak dit 'n krisis in die gemeenskap, omdat normatiewe waardes in die openbare sfeer gerelativeer word en morele verlamming so na vore tree.

Vir Boshoff (1995:20) is dit vir die kerk nodig om 'n Christelike etos met Christelike deugde te vestig. Stackhouse (1995:31) bevestig dit deur klem te lê op die vernuwing van morele waardes. In dié proses behoort daarteen gewaak te word om hierdie riglyne in absolute sisteme te omskep, aangesien die postmoderne mens (en lidmaat) agterdogtig is teenoor totaliserende sisteme. Die bedoeling van 'n normatiewe Christendom gaan eerder oor die skep van 'n oorkoepelende 
raamwerk wat mense help om sinvol binne die wêreld te leef - die daarstelling van lewensnorme wat rigting gee van wat behoort en wat nie (Van der Walt 1999:18). As ons God werklik in hierdie wêreld wil dien, dan is duidelike norme onontbeerlik en behoort die kerk die samelewing daarop te wys dat dit die medeverantwoordelikheid vir morele herstel het (Van der Walt 1999:47).

\section{Bousteen 6: Gemeentes moet verstaan word as geloofsgemeenskappe.}

Aangesien daar ' $n$ waarde-diversiteit onder wit mense is, is daar nie meer sprake van ' $n$ tipiese manier van dink en doen nie (Boshoff (1995:28). Daar is ook 'n geestelike fragmentasie wat volgens Durand (2002:60-61) lei tot die groot verskeidenheid godsdienstige en liturgiese gebruike in gemeentes van die NG Kerk. In dié verband verwys Steyn (2006:1) na vyf groot bewegings (neigings) omtrent spiritualiteit wat tans in die NG Kerk bestaan: tradisioneel (verwysend na die gereformeerde tradisie), charismaties, rasionalisties (intellektuele bewegings), mistiek (met 'n kontemplatiewe fokus) en sinkretisties (eie gekonstrueerde godsdienssiening). In baie gemeentes word gepoog om verskillende vorme van spiritualiteit te akkommodeer, omdat die fokus op die direkte godsdienstige belewenis is. Wanneer dié diversifisering die bediening van die gemeente begin bepaal, is die gevaar dat die gemeentelewe tot ' $n$ tipe verbruikersgodsdiens vervlak word (Boshoff, 1995:34).

Hierdie geestelike fragmentasie bring nie net verskeidenheid binne gemeentes nie, maar ook tussen gemeentes van dieselfde verband. Gemeentes funksioneer ook al meer onafhanklik van die res van die kerkverband (Durand 2002:61). Die vryheid van keuse in die 'godsdienstige mark' wat aangehelp word deur utilisme en pragmatisme bring ' $\mathrm{n}$ kongregasionalistiese ingesteldheid binne die gereformeerde kerke tot stand. Die diversiteit van spiritualiteite en die individualiteitskarakter in gemeentes veroorsaak dat gemeentes iets van hulle karakter as geloofsgemeenskap begin verloor. Dit noodsaak 'n nadenke oor 'n saak wat volgens Hunsberger $(2002: 97,99)$ fundamenteel is vir die hedendaagse kerk - dit is die herstel van die gemeenskap van gelowiges. Die huidige generasie se verbintenisse tot sosiale instellings (soos die kerk) hang af van die mate waarin ' $n$ individu se sosiale behoeftes sinvol bevredig word. Om die gemeenskap te herstel, word individualiteit nie misken nie, maar word veronderstel dat die individu juis tot sy reg kom as gevolg van sy sinvolle verbintenis met die geloofsgemeenskap. Hunsberger (2002:100) wys daarop dat die uitdaging vir die kerk is om ' $n$ gemeenskap te wees wat deur die evangelie gevorm word. Sonder om te verabsoluteer, behoort daar 'n raamwerk van praktyke en denkpatrone gevestig te word wat dié van Jesus Christus insluit. Dit behoort gemeentes se grootste gemene deler te wees omdat dit die standaard is waarteen die kerk (en 'n gemeente) se oortuigings en aksies beoordeel kan word. Die postmoderne veranderinge maak dat mense soek na 'n demonstrasie daarvan (Hunsberger 2002:103).

\section{Bousteen 7: Herwaardeer die NG Kerk se gereformeerde tradisie.}

As die kerk relevant wil wees, behoort dit ook duidelikheid te hê omtrent sy identiteit waardeur dit gerig kan word. Daar is diversiteit in die NG Kerk wat positief aangewend kan word, maar sonder 'n duidelike identiteit waaraan die diversiteit georiënteer kan word, kan dit eerder verwarrend en verdelend wees (Burger, 2005:7). Burger (2001:17) formuleer dit soos volg: "Sonder 'n lewendige en diepgaande gesprek oor ons gereformeerde erfenis, gaan ons nie goeie vernuwing in die NG Kerk kry nie." 'n Belangrike deel van die besinning oor identiteit is die herwaardering van die NG Kerk se gereformeerde tradisie.

By die Algemene Sinode van 2004 word aanbeveel dat 'n omvattende ondersoek onderneem word omtrent die volgende: die wyse warop die Gereformeerde identiteit van die NG Kerk tans funksioneer in die teologie en bedieningspraktyk van gemeentes; hoe die Gereformeerde identiteit verstaan behoort te word te midde van die verskeidenheid ten opsigte van teologie, 
bediening en spiritualiteit in die NG Kerk; die wyse waarop daar in die toekoms gestalte gegee moet word aan die Gereformeerde identiteit met die oog op die opbou en groei van die NG Kerk (Handelinge van die Algemene Sinode, 2004:303).

Vir Burger is daar vanuit die gereformeerde tradisie self bruikbare wesenskenmerke wat die kerk in die toekoms kan lei op die pad van verantwoordelike verandering en vernuwing. Hy noem die volgende (Burger 2001:18, 19, 21-22, 23-24):

In die gereformeerde tradisie is daar' $n$ soeke om God in alles sentraal te stel. Die uitdrukking van Calvyn dat daar voortdurend tyd ingeruim moet word om "die gesig van God te bedink", behoort die kerk te rig om God self te eer en te verheerlik in alles wat dit doen. Hierdie oortuiging bied 'n teen-sekulariserende krag.

Ten spyte van die uitdagings van diversiteit is daar by die NG Kerk steeds ' $n$ diep verbintenis aan die eenheid van die kerk. Hoewel die kerk in die verlede bande verbreek het, het die NG Kerk nou die geleentheid om nader aan die verskillende kerke in die familie en ook ekumenies te beweeg, want die kerke het mekaar nodig as hulle in hierdie tyd ' $n$ impak wil maak.

Burger meen dat gereformeerdheid altyd 'n groter geskakeerdheid getoon het as die meeste ander kerklike tradisies. Gereformeerdheid was nooit 'n monolitiese eenheid nie. Die NG Kerk verteenwoordig byvoorbeeld ' $n$ gereformeerdheid met evangeliese trekke wat teenoor die strammer Nederlandse gereformeerdheid staan. Hierdie variasie binne die gereformeerdheid veroorsaak dat daar nie 'n oormatige regulering in die kerk en tradisie is nie. In 'n tyd waarin pluraliteit op so baie vlakke 'n werklikheid is, behoort dit ook te help om makliker met verskeidenheid saam te leef.

Die geskiedenis van die gereformeerde tradisie wys volgens Burger uit dat daar binne die tradisie ' $n$ openheid is om voortdurend, ook in nuwe situasies, te reformeer. Vir Burger strook dit met die Protestantse beginsel wat behels dat ' $n$ historiese instansie, tradisie, gebruik of selfs ' $n$ belydenisskrif wat in die tyd ontstaan het, nie bo kritiek verhef kan word nie. Hierdie wesenskenmerk bring die vryheid om die teologie en die kerkpraktyk voortdurend te interpreteer in 'n poging om kontekstueel die historiese en teenswoordige bewussyn te verreken.

Burger (2001:48) verwys ook na Brian Gerrish wat meen dat gereformeerdheid nie in die eerste plek gaan oor ' $n$ stel waarhede wat oorgedra word nie, maar oor 'n manier van dink omtrent die waarheid van God en die lewe. Daar behoort gevra te word na die sentrale religieuse motiewe van die gereformeerde tradisie. Burger (2001:51-52) wys die religieuse motiewe aan wat die gereformeerde tradisie in beweging gebring het en steeds vir die NG Kerk belangrik is, aangesien dit te doen het met oortuigings, strewes en doelstellings wat vormend op die kerk kan inwerk:

\section{'n Lewe voor die aangesig van God (Coram Deo):}

Die Reformasie se soeke na God het opgekom uit 'n diepe behoefte aan sekerheid, vastigheid en vertroosting. Hoewel daar vandag baie mense is wat 'n misnoeë met die institusionele kerk het, is dit ook waar dat die hedendaagse mens 'n diep, ongeneeslike behoefte aan transendensie het (Burger 2001:58). Die skerp negatiwiteit van moderne mense teenoor die kerk kan egter as iets positiefs aangewend word wat bydra tot 'n suiweringsproses om die kerk skoon te maak van kerkgerigtheid en eerder mense voor God te bring (Burger 2001:61).

\section{Gebonde aan die Woord:}

'n Baie sterk gereformeerde beginsel is dat God deur sy Woord tot die mensdom spreek. Die postmoderne mens beleef egter 'n paradoks omtrent die Bybel, want enersyds word gestel dat die Bybel die Woord van God is en andersyds is die mens die vryheid veroorloof om dit krities te lees soos enige ander boek (Hofmeyr 2002b:46). Hoewel daar tans die vryheid is om uitsprake 
oor sekerhede en onsekerhede te maak, is die reformatoriese motief dat die Woord gesagvol is vir die lewe, steeds vir die voortbestaan (en identiteit) van die kerk van belang. Hierdie besef vind weerklank in die NG Kerk se verklarings tydens die Algemene Sinode van 2004: die Bybel is die Woord van God en het daarom gesag oor die hele lewe; dit is betroubaar omdat God Homself daarin bekend maak; dit is duidelik en voldoende omdat dit alles leer wat die mens hoef te weet om in God te glo en om sy wil te gehoorsaam. Die noodsaaklikheid van verantwoordelike Skrifuitleg word erken asook die relevansie van die Woord vir die hedendaagse uitdagende tye, omdat God steeds sy kerk daardeur in die waarheid sal lei (Handelinge van die Algemene Sinode 2004:434-435). Daarom sê Burger (2005:7): “Mense kan nie oor Christus dink en sê wat hulle wil nie. Wat ons saambind, is die feit dat ons Christene is, mense wat glo in die Christus van die Skrifte."

\section{Gerig op die lewe:}

'n Sterk punt in die gereformeerde tradisie is die oortuiging dat God nie die kerk wegvoer uit die wêreld nie, maar juis daarop rig. Die kerk word soms daarvan beskuldig dat dit nie altyd die kompleksiteit van die lewe verstaan nie. Vir Burger (2001:97-98) egter behoort dit een van die gereformeerde tradisie se sterkpunte te wees om op 'n dieptevlak na te dink oor die wêreld en dit te probeer verstaan. Interessant genoeg word daar gesê dat een van die redes waarom gereformeerde kerke tans 'n moeilike tyd beleef, juis daarmee saamhang dat hulle die komplekse wêreld probeer verstaan. Daarom meen Burger sal dit juis gereformeerdes wees wat die kerk van Christus gaan help om in die nuwe era 'n sosiale teorie daar te stel waarmee die kerk kan werk.

\section{Bousteen 8: Verreken die groeiende onderskeid tussen teologie en belydenis:}

Diversiteit van teologiese uitsprake is iets wat in die toekoms toenemend sal voorkom (Boshoff 1995:29). Hofmeyr (2002b:46) dui ook aan dat daar gedurende die laaste deel van die 20ste eeu (en sekerlik sedertdien) besliste teologiese aksentverskuiwings in die NG Kerk plaasgevind het. Hierdie verskuiwings hou verband met die teologiese 'vervanging van paradigmas' en het vir Küng (1989:4) te doen met die beweging weg van logiese positivisme en kritiese rasionalisme. Dit bring 'n mate van diskontinuïteit en konseptuele verandering van geldende oortuigings mee. Dit is sekerlik om dié rede dat daar by die Algemene Sinode van 1998 die volgende omtrent die teologie en sy verhouding met die kerk se geldende oortuigings gemaak word: "Daar moet duidelik tussen konfessie en teologie onderskei word, sonder om dié twee waterdig van mekaar te skei. ... [A]s sodanig bely die konfessies die gemeenskaplike geloof van die kerk, en nie die (wetenskaplike) mening van hierdie of daardie individuele teoloog nie. In die belydenis van die kerk gaan dit immers om die leer van die evangelie wat God in sy Woord geopenbaar het ... Daarnaas het die beoefening van die teologie, kragtens die wetenskaplike aard daarvan, dikwels met onsekere eksperimente, tastende beredenering en voorlopige resultate te make. Teoloë is altyd mense van hulle tyd met al die beperkinge wat dit vir hulle teologie meebring ... In die belydenisskrifte is ons konfessioneel aan die geloof verbind, nie aan die teologiese wetenskap nie." (Agenda van Algemene Sinode 1998:62 ).

Die kerk besef die nodigheid van 'n vaste raamwerk van oortuigings wat die kerk behoort te handhaaf, om sodoende rigting en standvastigheid aan die kerk te besorg in die hedendaagse wêreld van relativisme en pluraliteit wat ook sy merk laat op die akademiese basis van die teologie. 'n Gesprek omtrent die voorveronderstellinge van die verskillende strominge in die teologie behoort ook op 'n nie-bedreigende manier gedekonstrueer te kan word. Dit sal die geleentheid bied om die konseptuele verandering en verskuiwings in die teologie beter te begryp en te verreken. 
Vir Hofmeyr (2002b:45) staan die identiteit van die NG Kerk ten nouste in verband met die vraag: Wat is die diepste wese en wortels van die kerk? Om getrou aan die wese van die kerk uitdrukking te gee, maak die kerk geloofwaardig. Diepgaande onsekerheid hieroor veroorsaak dat die kerk in die pluralistiese wêreld (ook die pluralistiese godsdienstige wêreld) met sy veelvoud van alternatiewe, 'n onafgegrensde, plooibare identiteit ontwikkel wat maar net 'n afdruksel word van die wêreld om hom. Dit is dus belangrik vir die NG Kerk om duidelikheid te soek oor sy wese. In hierdie artikel is gepoog om by wyse van die 'boustene' waardes daar te stel wat duidelikheid bring omtrent wat vir die wese van die NG Kerk tans behoort te geld. Die waardes kom uit die geskiedenis van die NG Kerk en die konteks waarin dit bestaan, voort.

Middleton en Walsh (1995:28) wys daarop dat die hedendaagse wêreld besig is om nuwe antwoorde op die volgende vrae te soek en te formuleer: Waar is ons? Wie is ons? Wat is verkeerd? Wat is die oplossing? Toegepas op die NG Kerk kan die agt genoemde 'boustene' of waardes antwoorde bied op die bogenoemde vrae soos dit in die kerklike konteks gestalte kry. Op hierdie wyse kan daar verheldering kom vir die huidige situasie van die NG Kerk.

\section{BIBLIOGRAFIE}

Agenda van die tiende sitting van die Algemene Sinode van die Nederduitse Gereformeerde Kerk in Pretoria. 11-17 Oktober 1998.

ALEAZ, K.P. 2002. The globalization of poverty and the exploitation of the Gospel. (In Foust, T.F., Hunsberger, G.R., Kirk. J.A. \& Ustorf, W., eds. A scandalous prophet. The way of mission after Newbigin. Grand Rapids, MI : Eerdmans Publishing Co. p. 165-173.)

BECKER, L. 2006. 'n Praktiese strategie vir die NG Kerk. Kerkbode:12, Okt. 13.

BOSHOFF, H. 1995. Die kerk in die nuwe Suid-Afrika. Potchefstroom.

BURGER, C. 2001. Ons weet aan wie ons behoort. Nuut gedink oor ons gereformeerde tradisie. Wellington : Lux Verbi.BM.

BURGER, C. 2005. Diversiteit en identiteit. Kerkbode:7, Mrt. 25.

DAVIE, G. 1999. Europe: The exception that proves the rule? (In Berger, P.L., ed. The desecularization of the world: resurgent religion and world politics. Grand Rapids, MI : Eerdmans Publishing Company. p. 6583.)

DURAND, J. 2002. Ontluisterde wêreld: Die Afrikaner en sy kerk in 'n veranderde Suid-Afrika. Wellington : Lux Verbi.BM.

ERASMUS, J. 2004. Die toekoms van die kerk en die kerk van die toekoms. Kruisgewys, 4(2):7-8.

GAUM, F.M. 1981. Die kerk en die toekoms van Suid-Afrika. Pretoria : NG Kerkboekhandel Transvaal.

GAUM, F.M., samesteller. 1997. Die verhaal van die Ned Geref Kerk se reis met apartheid 1960 - 1994.

Wellington : Hugenote-Uitgewers (Algemene Sinodale Kommissie).

Handelinge van die twaalfde Algemene Sinode van die Nederduitse Gereformeerde Kerk in Hartenbos. 1015 Oktober 2004. (p. 270-452.)

Handelinge van die sewentiende Sinode van die Nederduitse Gereformeerde Kerk Suid-Transvaal in Alberton. 18-20 Oktober 2005. (p. 216-343.)

HANEKOM, B. 2007. Nuutste tendense in die NG Kerk. Kerkbode:9, Okt. 12.

HUNSBERGER, G.R. 2002. The church in the postmodern transition. (In Foust, T.F., Hunsberger, G.R., Kirk. J.A. \& Ustorf, W., eds. A scandalous prophet. The way of mission after Newbigin. Grand Rapids, MI : Eerdmans Publishing Co. p. 95-106.)

HOFMEYR, J.W. 2002a. NG Kerk: Waarheen? (In Hofmeyr G., red. NG Kerk 350 - Eenhonderd bakens in die geskiedenis van die Nederduitse Gereformeerde Kerk 1652-2002. Wellington : Lux Verbi.BM. p. 242243.)

HOFMEYR, J.W. 2002b. Die NG Kerk en kerkwees in ons tyd. (In Du Toit, P.R., Hofmeyr, J.W., Strauss, P.J. \& Van der Merwe, J.M. Moeisame pad na vernuwing. Die NG Kerk se pad van isolasie en die soeke na' $n$ nuwe relevansie 1974-2002. Bloemfontein : Barnabas. p. 1-50.) 
JONKER, W.D. 1998. Selfs die Kerk kan verander. Kaapstad : Tafelberg-Uitgewers.

KRUGER, P. 2008. 'n Dowwe spieël? 'n Kerkhistoriese ondersoek na die resente stand van die Nederduitse Gereformeerde Kerk, 1990 - 2006. Pretoria : Universiteit van Pretoria. (Verhandeling - MA Teol)

KÜNG, H. 1989. Paradigm change in theology: a proposal for discussion. (In Küng, H. \& Tracy, D., eds. Paradigm change in theology - A symposium for the future. New York, NY : The Crossroad Publishing Company. p. 3-33.)

MIDDLETON, J.R. \& WALSH, B.J. 1995. Truth is stranger than it used to be. Biblical faith in a postmodern age. Downers Grove IL : Intervarsity Press.

MOLTMANN, J. 1989. The interlaced times of history: some necessary differentiations and limitations of history as concept. (In Küng, H. \& Tracy, D., eds. Paradigm change in theology - A symposium for the future. New York, NY : The Crossroad Publishing Company. p. 320-339.)

OOSTHUIZEN, J. 2008. NGK wil rassisme aandurf. Kerkbode:1, Mrt. 21.

SMIT, D.J. 2001. Has there been any change? On the role of the Dutch Reformed Church 1974-1990. Scriptura, 76:119-126.

STACKHOUSE, M.L. 1995. Christian social ethics in a global era: Reforming Protestant views. (In Stackhouse, M.L., ed. Christian social ethics in a global. Nashville TN : Abingdon Press. p. 11-73.)

STEYN, G.J. 2006. Die NG Kerk se identiteitskrisis. Deel 2: Huidige bewegings, tendense of mutasies. [E-pos aan:] Kruger, P., 30 Sept. 2006.

TABER, C.R. 2002. The Gospel as authentic meta-narrative. (In Foust, T.F., Hunsberger, G.R., Kirk. J.A. \& Ustorf, W., eds. A scandalous prophet. The way of mission after Newbigin. Grand Rapids, MI : Eerdmans Publishing Co. p. 182-194.)

VAN DER WALT, B.J. 1999. Godsdiens en samelewing - Christelike betrokkenheid op die markplein. Potchefstroom. (Reeks F3: Versamelwerke van die Instituut vir Reformatoriese Studie, 1999:51.)

WESSELS, A. 2001. Die oorlog se bose kringloop. (In Pretorius, F., red. Verskroeide aarde. Kaapstad : Human \& Rousseau (Edms.) Bpk. p. 254-257.)

\section{TREFWOORDE}

Identiteit van die NG Kerk

Uitdagings aan die NG Kerk

Norme en waardes vir die NG Kerk

Toekoms van die NG Kerk

Boustene vir die toekoms

Teologie en belydenis

Postmoderne paradigma

\section{KEYWORDS}

Identity of the NG(DR) Church

Challenges to the NG(DR) Church

Norms and values for the DR Church

Future of the DR(NG) Church

Directives for the future

Theology and confession

Postmodern paradigm

Kontakbesonderhede:

Prof JW (Hoffie) Hofmeyr

Suite 191, P/Sak X025,

0040 LYNNWOODRIF

Selfoonnommer: 0824527778

E-posadres: linhof@mweb.co.za

\author{
Ds P Kruger \\ Posbus 570 \\ 1490 NIGEL \\ 0118144848 \\ 0826869217 \\ E-posadres: pkkruger@telkomsa.net
}

